\title{
PREVIEW: THE LINGUISTIC ATLAS OF THE MIDDLE AND SOUTH ATLANTIC STATES
}

Hans Kurath, Director, Linguistic Atlas of the United States and Canada Raven I. McDavid, Jr., Editor-in-Chief Raymond K. O'Cain, Associate Editor

George T. Dorrill, Assistant Editor

Sara L. Sanders, Assistant Editor

Fifty years after a Linguistic Atlas of the United States and Canada was proposed, the University of Chicago Press has begun the publication, in fascicles of 128 pages each, of the Linguistic Atlas of the Middle and South Atlantic States.

The third to be published in a series of autonomous regional atlases, the Atlas of the Middle and South Atlantic States and the previously published Linguistic Atlas of New England present a picture of the speech of the Atlantic seaboard, from which other varieties of American English are derived. Familiarity with these atlases is indispensable for interpreting the findings of the other regional surveys such as the Linguistic Atlas of the Upper Midwest (197376), and forthcoming atlases of the North-Central States, California-Nevada, Oklahoma and the Gulf States.

The published atlas will total 8000 large octavo pages including a complete word index. Fascicles will appear as editing progresses. A Handbook of some 500 large octavo pages is scheduled for completion in 1980.

The Atlas will present the full phonetic data on 787 principal items, systematically investigated, and a large number of significant if less widely distributed items that were recorded in the course of the interviews. Items investigated include geographical and topographical terms, numerals, time and the weather, farming, domestic and wild animals, trees and shrubs, food and cooking, family and social relations, mental and physical states, inflections, and syntax.

The Handbook will include (1) a brief history of the population of the Middle and South Atlantic States, with population maps and a select historical bibliography; (2) a concise account of the dialect areas, with charts and a selected bibliography of lingui stic geography; (3) information required for the proper interpretation of the Atlas data: worksheets, communities and informants, the phonetic alphabet, field practice, editorial procedure, suggestions for the historical interpretation of the linguistic material.

\section{Plan of the Atlas}

The Linguistic Atlas of the Middle and South Atlantic States, like the Linguistic Atlas of New England, follows the method of field recording first employed by Jules Gillieron in the Atlas Linguistique de la France (1902-10) and later by Karl Jaberg and Jakob Jud for the Sprach- und Sachatlas Italiens und der Sudschweiz (1925-40).

The Atlas of the Middle and South Atlantic States presents the usage of 1216 informants (including 16 in Ontario, 44 in Ohio, 20 in Kentucky, and 9 in 
Florida), in 518 communities (including 10 in Ontario, 18 in Ohio, 7 in Kentucky, and 5 in Florida). All interviews were conducted by trained investigators in the homes of the informants, and for all but a few interviews phonetic transcriptions were made on the spot. Interviews averaged about eight hours.

Of the 1216 field records, 840 were made by Guv S. Lowman, Jr. , principal field worker for New England; 304 were made bv Raven I. McDavid, Jr., who who was trained by Bernard Bloch, assistant editor of the Atlas of New England. In addition, McDavid transcribed from tape 61 interviews by others. Thus all but 11 field records represent the transcription of two investigators.

(1) Like other American regional surveys, the Atlas of the Middle and South Atlantic States recognizes that folk speech in the United States is not sharply different from cultivated speech and that there is normallv an interplay between class dialects. Consequentl $v$. instead of a single informant in a community, the investigators normally interviewed two--one with a minimum of education and travel (sometimes illiterate), the other with some years in high school. Furthermore, cultured informants have been included in 112 communities; such informants are identified on the tables with underlines. In a number of communitles (e.g. . New York Clty, Philadelphia, Charleston, Atlanta) more than three informants were included, and severa! of the cultivated type. The Linguistic Atlas of the Middle and South Atlantic States thus presents the speech of three cultural levels. This practice is helpful in determining linguistic trends locally and over large areas, and in providing a frame for more intensive sociolinguistic studies (the exact number of social/cultural groups in any community can be determined only by consulting the people of that community).

(2) The informants were not asked to give "dialectal" equivalents for expressions of the literary language, as was often done in Europe. Instead they were asked to name objects, actions, qualities, etc., which the investigator elicited by description, gesture, and linguistic context.

The tapes from which transcriptions were made have been deposited in the Center for Folklife at the Library of Congress. Copies may be obtained from the Center.

Make-up of the Tables

The Linguistic Atlas of the Middle and South Atlantic States differs from that for New England in that the evidence is not presented on maps but in tables. There were several reasons for this decision. The cost of producing large hand-lettered volumes like those for New England is prohibitive. They are difficult to shelve and handle--and LAMSAS has nearly three times as many interviews as LANE. Cartographic presentation, furthermore, imposes an invariable format on items of highly variable complexity. One may compare the New England maps for round clam (235), sycamore (244), and ran (658) with those for privy (354) and doughnut (284). For the first three there a re wide areas of empty space; for the last two, the responses and commentary fill the page--and for doughnut the commentary must be carried over to the succeeding map. A list, In contrast, may be as long or as short as the data requires; successive non-responses, or identical responses, may be consolidated. But most 
important, those who have worked with lists find them far more convenient than maps for making interpretive charts of single features and for disclosing social differences.

The lists are produced by photo-offset from copy typed with an IBM Selectric II. Each list presents, in principle, the usage of all informants on one particular form either the terms used for one and the same thing (e.g. , List 148 field), or the varying pronunciations of one and the same word (e.g. , List 5 Massachusetts) or else the grammatical forms or constructions employed in a given situation (e.g., List 54 miles). Tables for words and grammatical forms inevitably present additional valuable phonetic evidence, since all responses were recorded in phonetic notation using the alphabet of the International Phonetic Association, with certain refinements and alterations. To present the phonetic material, the staff developed a special Selectric element (Camwil $1873-\mathrm{M})$; infrequent symbols are typed with other elements.

The sample in this article shows the make-up of the tables; on the base map the location of the communities is indicated by numbers. A copy of this map is included in the first fascicle of each volume of the Atlas; the University of Chicago Press has given its permission to subscribers to make copies for charting. Within each state the sequence of communities is by numbers; within each community the sequence of informants is alphabetical, in terms of cultural sophistication, the least sophisticated white informant always being a. Negro informants are indicated by the letter $\underline{N}$ prefixed to the community number; in rural communities, where they are usually the least sophisticated informants, their responses are given first; exceptions have been made where in the judgment of the editors they are warranted. Every cultured informant is indicated by an underline. The order of informants is the same on all charts, from Onta rio $1 \mathrm{a}$ to Florida $5 \mathrm{~b}$.

The name of the field worker who interviewed each informant is given in the table of informants by types, which also indicates the sex and cultural status of each informant as well as the date of the interview and the age of the informant when interviewed.

With each list a commentary is provided. Where necessary, it describes briefly the method of asking the question, the range of the meanings of the terms, and the character of the object denoted. Moreover, it reproduces definitions and significant comments by informants and field workers concerning the currency and the social status of words, forms, pronunciations, and constructions.

The lists of the Atlas of the Middle and South Atlantic States thus offer detailed and authentic Information concerning the spoken English of the Atlantic seaboard. It will be the task of the linguist to study the evidence in the light of the population history: original settlement; later shifts in population; the development of trade centers; communication by land and water; the industrial development in the nineteenth century: the press, schools, colleges, churches, and other cultural agents. The data and the cultural analysis will make it easier to interpret the findings of more recent intensive studies. 


\section{Historical Interpretation}

Although a full historical interpretation of the development of the speech of the Middle and South Atlantic States will require much arduous work, some of the forces that have shaped it and are influencing it now can be perceived.

The several distinct groups of settlements from Long Island to the Altamaha (the Hudson Valley, East and West Jersey, Pennsylvania, Chesapeake Bay, the Carolinas and Georgia) had different mixtures of English stock. They came from various parts of England, the proportions ranging from settlement to settlement; others came from New England, Bermuda, and Barbados. Interspersed with these were compact settlements of Highlanders, Ulster Scots, and Welsh. The colonies on the Hudson and the Delaware had already been settled by Dutch, Swedes, and Finns. Communities of Germans, German-Swiss and Huguenots were established from the Mohawk to the Savannah, and the major ports of New York, Philadelphia, and Charleston were polyglot communities. The process of completing the coastal settlements extended over a century and a quarter, from Jamestown (1607) to Savannah (1733). As they were consolidated and profitable export agriculture developed, the need for labor was met by transported criminals (English), indentured servants (English, Scots, Irish, and Germans), and slaves (blacks imported from Africa, sometimes by way of the West Indies). During the century and a quarter of settlement, each colony pushed inland from its coastal base; isolation, rivalries, separate political and cultural systems fostered provincial dialects. These dialects are still reflected in the twentleth-century distribution of words and pronunciations: one may consult table 353 pot cheese 'cottage cheese' (Hudson Valley); table 283 spindle 'dragon fly' (New Jersey); table 581 bagged school 'played hookey' (Philadelphia); table 182 toot 'paper bag' (Pennsylvania Germans); table 340 batter bread 'soft cornbread' (eastern Virginia); table 230 hum 'moo' (eastern North Carolina); table 312 mutton corn 'sweet corn' (the South Carolina Low-Country); and table 360 cripple 'scrapple' (the Savannah Valley).

From 1740 to the Revolution, two major migrations began to carry Atlantic Seaboard speech westward and southwestward. From Vermont and western Massachusetts settlers moved into upstate New York; from Connecticut into the Delaware and Wyoming Valleys of northern Pennsylvania (territory claimed by Connecticut under its earlier charter). At the same time, restrictive British policies in Northern Ireland encouraged the overseas migration of Ulster Scots. Many of them came to various colonies as indentured servants; others estabUshed small communities as far apart as southern New Hampshire and the Catawba Valley of South Carolina. The largest group settled in central Pennsylvania, where they became the cutting edge of the frontier; with some help from Virginia they built up Pittsburgh and dominated the upper Ohio Valley; another group, reinforced by Pennsylvania Germans, moved southwest through the Great Valley, sending out branches in several directions: through the Kanawha Valley to the Ohio; from the Shenandoah into the upper Tennessee Valley; along the eastern slopes of the Blue Ridge and thence (a) northwestward into Kentucky through the Cumberland Gap, and (b) reinforced from the Virginia Piedmont, into the Piedmont of the Carolinas and Georgia. As the result of these 
migrations three principal dialect regions (with various sub-areas; see Kurath 1949) have been established as far west as the Mississippi Valley, with effects beyond: a Northern area stemming from New England, sharply set off from a Midland area stemming from Pennsylvania, in turn sharply set off along the Atlantic seaboard from a Southern area based in the old plantation country. The nineteenth-century expansion of the plantation system into territory first settled from Pennsylvania has blurred the Midland/Southern boundary even in South Carolina and Georgia.

Innovations have spread from various centers: New York (not so much its local forms as those it shares with the rest of the Hudson Valley, e.g. , cherry pit, table 323); from philadelphia (e.g., flannel cake, table 341); from charieston (e.g. , the vowel of boat, table 215); and from the Virginia Pledmont (e.g. . nicker 'whinny,' table 233 which in the Middle West has become the characteristic Midland term). The chief early advantage of Chesapeake Bay--deep water anchorages every few miles--was a disadvantage to urban development for the first century, when tobacco could be loaded at any planter's wharf and there was no need for ports. Only when the tidewater tobacco lands were exhausted and the plantation moved inland did Virginia develop urban communities; Alexandria, Fredericksburg, Richmond, and Petersburg on the fall line; Norfolk at the mouth of the Bay. At the same time Maryland developed its urban communities: Annapolis, Georgetown (opposite Alexandria on the Potomac), and (just before the Revolution) Baltimore at the head of the Bay. Further south, Savannah and Jacksonville became important ports in the nineteenth century; and after the Civil War Atlanta grew as a rallroad hub--the first major American city to develop without water transportation. The serious urban development of Washington came later, out of several national crises--among them the Civil War, two World Wars, and the painful recovery following the financial collapse of 1929. For all metropolitan a reas the suburbanization of the automobile age is imperfectly reflected in the Atlas, but the records provide irreplaceable evidence on the linguistic forces that have moulded present-day urban speech. Likewise, the inclusion of Negro informants--of various social groups--provides historical clues to black/white speech relationships that must be considered in any serious treatment.

The influence of the press, of the schools, and of commerce is shown in the spread of book words and standard grammatical forms and pronunciations. These influences, though everywhere present, have had different effects in various states: dreen 'drain' is rare in Pennsylvania, common in New York and Maryland. Regionally, they have been more important in the North and in Pennsylvania than further south, where a predominantly rural society, tardy industrialization and urbanization and education (state support for public schools in the South dates from the Reconstruction governments; effective public education came much later), the devastation of the war, and more casual social attitudes have preserved in the casual speech of educated Souinerners many features that elsewhere do not exist or are limited to folk speech (e.g. , used to didn't table 750).

As with the Linguistic Atlas of New England, the mid-century distribution of dialect features by sections, by social levels, and by age groups--as 
documented in this Atlas--will enable us to determine the trends of the recent past and interpret the speech of the present. Evaluation of these trends will facilitate the reconstruction of Atlantic Seaboard speech before the industrial era, and in turn lead toward the reconstruction of colonial speech and its relatlonship to the regional speech of the British Isles. A start in this direction has already been made by Kurath, Lowman, Sen, and others. Over the half century since the Lingulstic Atlas project was first suggested, there has been increasing interdisciplinary cooperation with demographers, historians of various interests, folklorists and cultural geographers. The publication of the Atlas of the Middle and South Atlantic States will increase that cooperation, both for what it contributes in Itself and for its value in interpreting the regional studies completed or in progress further west.

\section{History of the Atlas Project}

The Linguistic Atlas project was initiated in December 1928 by the Present-Day English section of the Modern Language Association of America and by the Linguistic Society of America. A conference in February 1929, sponsored by the National Council of Teachers of English, drafted a definite proposal to the American Council of Learned Societies; a conference in August of that year submitted a comprehensive plan to the ACLS. In January 1930, the ACLS endorsed the Atlas in principle, but recommended a pilot project over a restricted geographical area. Accordingly, speciflc plans were devised for a study of New England. Field work was completed in two years (1931-33); the first volume and the Handbook appeared in 1939 and publication was completed in 1943. (The Atlas of New England was reprinted in 1972, and a second edition of the Handbook was issued in 1973.)

Kurath next planned an Atlas of the South Atlantic States, but the 1929 depression cut so deeply into potential sources of funds that only one investigator, Guy S. Lowman, Jr. , could be kept in the fleld. By 1937 he had completed a wide-meshed survey from Delaware to central Georgia and a systematic investigation of Virginia and North Carolina. A year's interlude for Lowman in England yielded a survey of folk speech for comparison with American usage; by 1942 he had completed Delaware, Maryland and (for the proposed third regional survey of the Middle Atlantic States) Pennsylvania, New Jersey, West Virginia, metropolitan New York and the Hudson and Mohawk Valleys. His death in an automobile accident left incomplete the work in South Carolina, Georgia, and upstate New York. Kurath had already invited McDavid to complete South Carollna and Georgia; the involvement of the United States in World War II postponed the work, but by June 1949, it was completed according to Kurath's specifleations.

Editorial work on the South Atlantic Atlas had begun while the New England Atlas was taling final shape. Several hundred list manuscripts had been started and for about 200 items the draftsmen had prepared the hand-lettered overlays for overprinting, as far as the evidence was available. But as students and draftsmen were involved in World War $\Pi$, the pace of editing slowed, stopping altogether in 1946 when Kurath became editor of the Middle English 
Dictionary and moved with the Atlas archives to the University of Michigan.

Although Michigan provided handsome quarters for the Atlas project, it was unable to raise funds or provide editorial assistants for Kurath, who found the Dictionary a full-time activity. It subsidized the publication of four interpretive volumes: Kurath's Word Geography of the Eastern United States (1949) and his Phonology and Prosody of Modern English (1964), E. Bagby Atwood's Survey of Verb Forms in the Eastern United States (1952), and Kurath and McDavid's Pronunciation of English in the Atlantic States (1961). But no one came forward to carry on the work, so that with the approval of the ACLS, Kurath transferred the Atlas collections to McDavid, at the University of Chicago.

Since Chicago provided McDavid half time for Atlas work, he was able to resume editing according to Kurath's new plan--a single Atlas of the Middle and South Atlantic States to be printed by photo-offset from typed copy. The decade 1964-74 was spent consolidating the archives, arranging for additional interviews (which McDavid transcribed from tapes) in the sparsest-covered areas of South Carolina, Georgia, and upstate New York, redrafting editorial plans, and designing the phonetic element for the Selectric. With the help of A. L. Davis, of the Illinois Institute of Technology, a great deal of progress was made; hut it was still impossible to obtain funds or personnel for full-scale editorial operations; and again, no one at Chicago appeared willing and able to share the editorial burdens. In 1974-76, therefore, the Atlas archives were transferred again, this time to the University of South Carolina, with assurance of editorial support and adequate quarters and equipment.

The transfer was made possible by a fortunate conjunction of forces: McDavid, a native South Carolinian, had always felt an obligation to his home state--and not least to his father, who had taught him much of the human side of field work; Raymond O'Cain, another South Carolinian, who had worked with McDavid at Chicago, had joined the South Carolina faculty; a number of senior faculty members and citizens of Columbia--notably John R. Welsh, University provost; Milledge B. Seigler, senior professor in the University; Kenneth Toombs, Director of Libraries; and W. D. Workman, Jr., editorial consultant for The State newspaper--understood the value of the work and the significance of its presence at Carolina. The University has twice arranged for McDavid to provide on-the-spot supervision while teaching as a visiting professor. The National Endowment for the Humanities has provided a generous grant for editorial work, and a senior Fellowship to further McDavid's work on the Handbook. In addition to the institutional support by the various host universities--Yale. Brown, Michigan, the Illinois Institute of Technology, Chicago, and South Carolina--the Atlas has received continuing moral and financial support from the American Council of Learned Societies and from such institutions as the American Philosophical Association, the Johns Hopkins University, the University of Virginia, Duke University, and the University of North Carolina. This support was made possible by the active interest of such scholars as Leonard Bloomfield, Edward Sapir, Edgar H. Sturtevant, Paull F. Baum, and such laymen as H. L. Mencken. The development of the Selectric element was made possible by contributions from the Center for Applied Linguistics, the National Council of Teachers of English, and individual contributions. Work on the 
Handbook has been advanced by the cooperation of many research libraries-notably the Newberry Library of Chicago, the New York State Historical Association at Cooperstown, the Pennsylvania Historical Society of Philadelphia, the North Carolina Collection at Chapel Hill, and the Caroliniana Library of the University of South Carolina. Even more than the Atlas of New England, the Linguistic Atlas of the Middle and South Atlantic States is a cooperative enterprise in which American scholarship is represented by the contributions of the ACLS, organizations, and individuals.

University of Michigan University of Chicago Louisiana State University University of South Carolina

\section{REFERENCES}

Atwood, E. Bagby. 1953. A survey of verb forms in the eastern United States. Ann Arbor: University of Michigan Press.

Kurath, Hans. 1949. A word geography of the eastern United States. Ann Arbor: University of Michigan Press.

- 1964. A phonology and prosody of modern English. Ann Arbor: University of Michigan Press.

- 1970. English sources of some American regional words and verb forms. American Speech 45.60-68.

- 1972. Relics of English folk speech in American English.

Studies in Unguistics in honor of Raven I. McDavid, Jr., ed. by Lawrence M. Davis (University, Alabama: University of Alabama Press) 367-75.

- and Guy S. Lowman, Jr. 1970. The dialectal structure of Southern England: phonological evidence. Publication of the American Dialect Society 54.

, and Raven I. McDavid, Jr. 1961. The pronunciation of English

in the Atlantic States. Ann Arbor: University of Michigan Press.

, et al. 1939. Handbook of the linguistic geography of New

England. Providence: American Council of Learned Societies 1973. 2nd ed., with word index and map inventory by Audrey R. Duckert, New York: AMS Press.

- 1939-43. Linguistic atlas of New England. 3 vol. bound as 6 . Providence: American Council of Learned Societies. 1972. reprinted, 3 vol. New York: AMS Press.

Sen, Ann Iouise. 1973. The linguistic geography of eighteenth century New Jersey speech. Diss (microflim) Princeton University. 


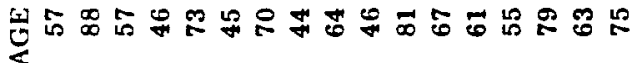

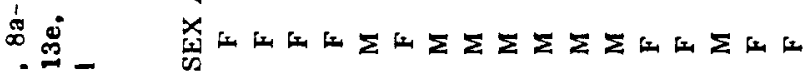
$\therefore \frac{\bar{q}}{10}$ is

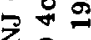
iे

จิ 茖 造娄 된

का 要 5 政 㠃

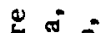
东

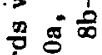

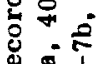

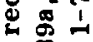

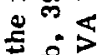
跣 年 $<$ 它要 㐫 क्ष 3 的急定

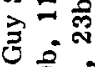

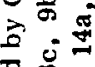

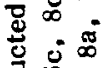

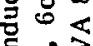
晏安

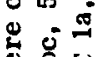
要解

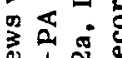
政 웡 is

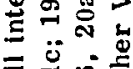
离

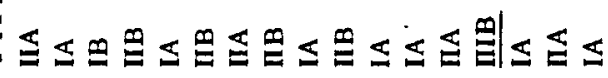

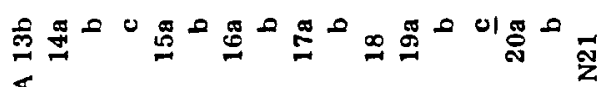

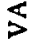

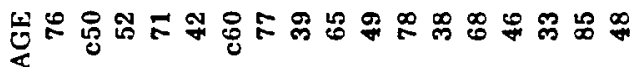

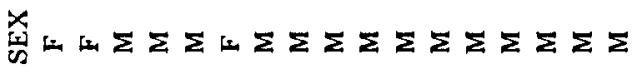

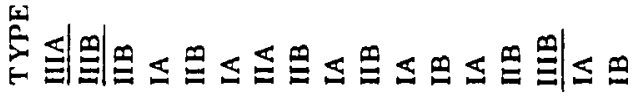

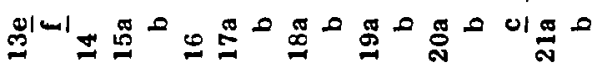
主

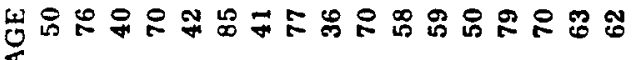

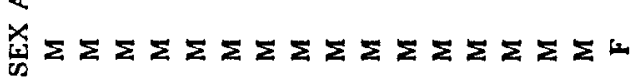

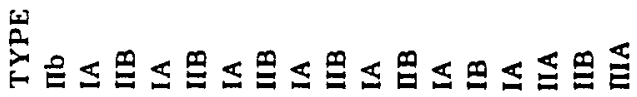

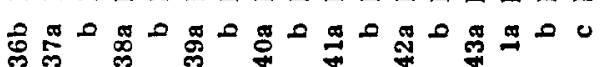
的

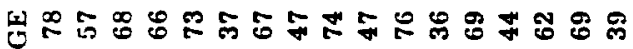

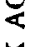

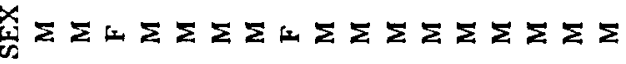

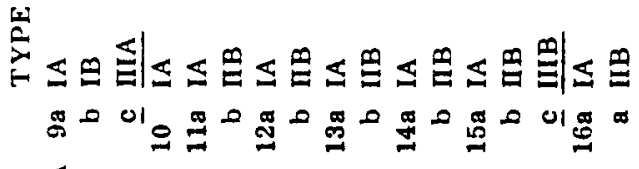

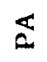

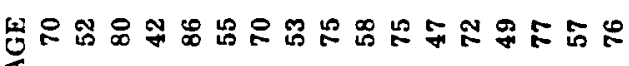

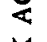

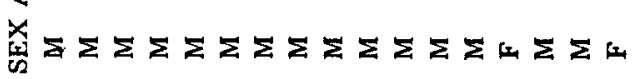

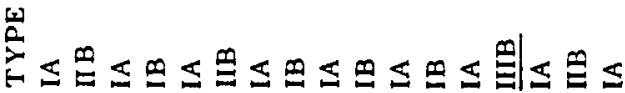

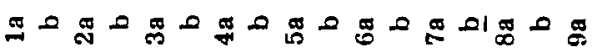
z

$\stackrel{\mathscr{2}}{ \pm}$

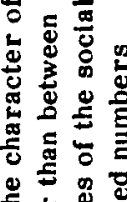
ذ屯 s.

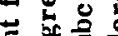
范 栗

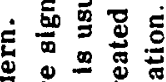
ซั ह

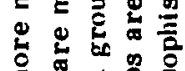
क

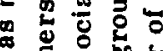

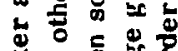

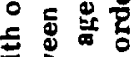
年 政 政 政

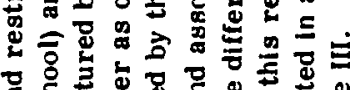

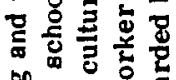

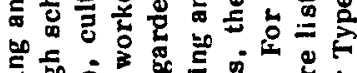

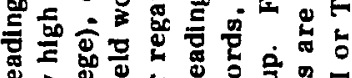

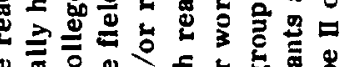

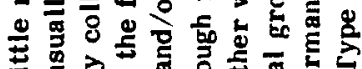

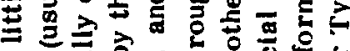
-

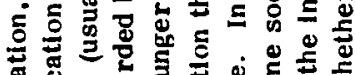
क्ष

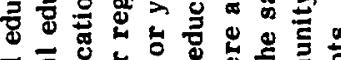

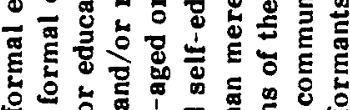

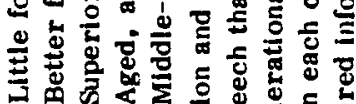

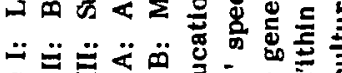

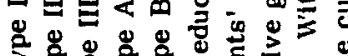

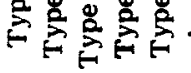
要密密 